\title{
Intended Consequences: Jurisdictional Reform and Issue Control in the U.S. House of Representatives
}

\author{
E. Scott Adler \\ (Univ. of Colorado/Yale Univ.) \\ John D. Wilkerson \\ (University of Washington)
}

\begin{abstract}
The power of congressional committees rests in large part on their ability to set the legislative agenda in particular issue areas. But how do committees acquire their issue jurisdictions? Existing research points to informal committee turf wars - not collective reforms - as central to explaining jurisdictional allocations (King 1994; 1997). Yet, since 1973, the House of Representatives has made nearly 150 formal changes to its committees' jurisdictions. We investigate the effects of one prominent instance of extensive jurisdictional changes, the Bolling-Hansen reforms of 1975, and find that it advanced collective goals of improved policy coordination and enhanced information sharing.
\end{abstract}

\section{Introduction}

When the U.S. Department of Homeland Security was created in 2003, dozens of congressional committees and subcommittees possessed jurisdiction over aspects of the new agency's functions and programs (Cohen, Gorman, and Freedberg 2003). Many legislators expressed the view that a rearrangement of jurisdictions in Congress was critical to fighting terrorism. This was also the primary recommendation of the $9 / 11$ Commission (National 
Commission 2004). Nevertheless, the matter was highly contentious. Said one legislator, "the "war on terrorism' has just expanded to the war on [jurisdictional] turf" (Nather and Foerstel 2002).

The homeland security issue highlights important questions regarding committee agenda control. The committee of jurisdiction possesses nearly exclusive rights to review legislative proposals and set the agenda in a particular policy arena. Thus, it is not surprising to learn that attempts to reconfigure existing jurisdictions are controversial. But what motivates the controversy?

Extant research highlights distributive concerns as the central barrier to reform. Committees resist change, not because they believe that it will be detrimental to the institution, but because it is detrimental to their own electoral and career goals (Adler 2002). This approach is consistent with a longstanding research perspective that portrays legislative institutions as structured to serve members' individual electoral needs (Mayhew 1974; Shepsle 1978).

Yet opponents as well as supporters of reforms typically offer collectively-centered justifications for their positions. For example, an observer of the Homeland Security dispute noted that much of it focused on whether a realignment would better serve the nation's security concerns:

Supporters of reform charge those who opposed the measure with putting turf protection above national security. But those concerned about the changes say they risk discarding the expertise of lawmakers and their staff, painstakingly built up over the years. Supporters of Rep. John Mica, R-FL., chairman of the Aviation Subcommittee, for instance, argue the subcommittee's expertise with aviation security would be lost in the proposed structure, just as the well of experience is running dry at the department itself, with more than half its senior leadership departing. (Waterman 2005) 
Transferring authority over all of the Homeland Security Department's functions to a newly created committee could be detrimental to the Congress's ability to legislate aviation security. Informational theories posit that divisions of labor encourage specialization and the acquisition of expertise (Gilligan and Krehbiel 1990). Thus, stable jurisdictions serve collective needs. But if this is the case, then when, if ever, are transfers of control justified? Existing research does not adequately address this question. Indeed, the conclusion of the literature is that formal reforms warrant little attention.

Using newly available data, we investigate the effects of the numerous formal changes that have occurred in the recent past by asking whether they altered what Evans (1999) calls the best measure of jurisdiction - where bills are referred. Our focus is on the Bolling-Hansen House reforms of 1975. These reforms produced the largest batch of jurisdictional changes ( 58 in all) of the past 60 years. The consensus of the congressional committee literature is that these reforms had little impact on issue control. King concludes that the "1974 'reforms,' whether expanding or subtracting from a committee's statutory jurisdiction, reflected the incremental common law changes that had been in force, in some cases, for decades" $(1994,58)$. Wolfensburger describes the same reforms as leaving "existing turf arrangements virtually intact" $(2004,2)$. Reformers did gain only a portion of what they originally sought (Davidson and Oleszek 1977; Adler 2002). However, no study has carefully investigated the consequences of the changes that were adopted.

In this paper we ask whether the Bolling-Hansen reforms altered control over a number of important issues. We then test alternative explanations for the changes that were adopted. The findings offer limited support for distributive and path dependent accounts of jurisdictional stability and change, and substantial support for the notion that the purpose and effect of the reforms was to 
better coordinate control over related issue areas - the same goal articulated during the homeland security debate.

\section{Issue Jurisdictions, Committee Power, and Motivations for Change}

A committee's agenda setting power derives primarily from its jurisdiction. Political scientists have sometimes defined jurisdiction in terms of the policy activities of congressional committees (such as hearings), but jurisdiction also has a formal definition within Congress (Tiefer 1989; Oleszek 2003). The House and Senate rules define jurisdiction in terms of which committees are entitled to review bills. For example, House procedure (Rule X) specifies that the Agriculture Committee possesses statutory jurisdiction over 20 subjects, including "agriculture generally," as well as "entomology and plant quarantine" and "rural electrification." Rule X also provides little leeway regarding referrals: "All bills, resolutions, and other matters relating to subjects within the jurisdiction of the standing committees listed in this clause shall be referred to those committees."

The bills committees report "largely determine what each chamber will debate" (Davidson and Oleszek 2004, 226). A mere 1 percent of the bills passed by the House of Representatives circumvent this process. Members of the committee of referral sponsor about 80 percent of the bills that their committees report, and these bills have an 80 percent chance of passing the chamber, compared to just 7 percent for bills in general (Wilkerson et al. 2003). The vast majority of bills (80-85 percent, depending on the Congress) are also referred to just one committee. Multiple referrals and the rare bills that circumvent the committee process entirely are the noteworthy exceptions to this pattern (though multiple referrals often limit each committee's role to the sections of the bill that fall within its jurisdiction) (Young and Cooper 1993; King 1997, 101-04).

These prerogatives give committee members "disproportionate access into the crucial early stages of decision making and a valuable forum for position-taking and credit claiming” (Evans 
1999, 610). Committee agenda control may be less important in eras of strong party leadership, but for many reasons, they continue to be important players in the process. According to Deering and Smith, "the dramatic flow of power to House Speaker Newt Gingrich, achieved during the watershed $104^{\text {th }}$ Congress, had reversed to favor committees and committee chairs as the $105^{\text {th }}$ Congress began" $(1997, \mathrm{xv})$. This same trend seems to be emerging after the "first 100 hours" agenda items were completed in the House at the start of the $110^{\text {th }}$ Congress (Weisman 2007, Eilperin and Grunwald 2007). Why does the House confer so much control over the early development of legislation to a limited number of lawmakers? The House standing committee system was created to promote efficiency by dividing responsibilities (Cooper 1974; Gamm and Shepsle 1988; Stewart 1989). However, scholars debate whether, in addition to efficiency, the particular arrangements of these divisions serve distributive, informational or partisan ends (Maltzman 1997). Distributive theories posit that the House delegates issue control to the members with the most to gain electorally (Shepsle 1978, Mayhew 1974; Shepsle and Weingast 1987). Informational theories posit that a central function of this division of labor is to promote the development and sharing of expertise (Krehbiel 1991). Partisan theories propose that committees exercise their agenda setting powers to advance the political and policy objectives of the majority party (Cox and McCubbins 1994).

Interestingly, even though jurisdictions define the power of committees, most of this research says little about jurisdictional reform. Other studies focus on the politics of reform but do not systematically examine its effects (Schickler and Rich 1997; Adler 2002; Cox and McCubbins 1994). As a result, what we do know about jurisdictions comes primarily from the work of King (1994; 1997) and scholars who study public policy agenda setting (Baumgartner and Jones 1991; 
Baumgartner and Jones 1993; Jones, Baumgartner and Talbert 1994; Hardin 1998a; Hardin 1998b; Baumgartner, Jones and MacLeod 2000).

According to King, jurisdictions develop informally and incrementally. Committees compete for control of new issues (or issues that cut across existing jurisdictional boundaries), by sponsoring bills and holding hearings with the intent of winning the first bill referrals by the parliamentarian. These first referrals create a track record of activity that strengthens the committee's case for subsequent referrals. Although the parliamentarian's referral decisions are guided by considerations of precedent and expertise, distributive considerations motivate committees to pursue jurisdiction in the first place. This research perspective further asserts that the effect of formal reforms is to "codify" practices established through this path dependent process: "Turf is gained through common law advances, not through formal rules changes (like the 'reforms' passed by the House in 1946, 1974, and 1980)" (King 1994, 48, 57).

Public policy agenda setting research highlights the dynamics of issue control, in contrast to the stable jurisdictional property rights implied in King's work and distributive theories of committee organization (Shepsle and Weingast 1987). Baumgartner and Jones argue that committees "are constantly changing their jurisdictions, both through attempts to grab parts of larger issues as they become more important and through unavoidable redefinitions as new policy problems rise on the governmental agenda" (1993, 660 emphasis added). Significantly, jurisdiction is usually defined in terms of a committee's broader activities, such as its proportion of all health hearings. This perspective also concludes that statutory reforms have limited effects for jurisdiction, but for very different reasons.

In sum, prior jurisdictional research suggests formal reforms have little impact on issue control in Congress either because their main effect is to formalize informally established bill 
referral practices, or because the statutory jurisdictions that are created do not really limit issue involvement by other committees. But if reforms can be expected to have little impact, then why do reformers promote them, and why are they so often controversial?

Legislators often behave as if they believe that jurisdictional arrangements matter and that reforms can make a difference. Speaking in favor of the Bolling-Hansen reforms, Representative Bill Frenzel (R-MN) complained:

Our structure and organization is so confused and our jurisdictions so scattered, that the House's effectiveness is sharply reduced. It would be terribly unfortunate if the House had to continue working under its outmoded and obsolete system of jurisdictions... Congress must organize itself so that it can unify its programs and policies in these important areas rather than continue to work on these problems in an uncoordinated and often counterproductive way. ${ }^{\mathrm{i}}$

Similar concerns were expressed in the more recent debates over homeland security:

My biggest problem with what is going on with homeland security is that it can be a very black hole with respect to resources spent in protecting this homeland and that when there is... [an] authorizing jurisdiction...between different committees, that maybe there isn't somebody really taking the whole picture of what are the limited resources and what are really the priorities that we have to do. And when you have something in transportation and something in intelligence and something in commerce and other issues, then everybody's trying to solve a problem, but nobody's really taking a look at the overall picture. ${ }^{\mathrm{ii}}$ 
These statements suggest that a central goal of jurisdictional reform is to better align committee control over related issues. This goal is controversial because it threatens status quo arrangements existing distributions of power or expertise structures. Nevertheless, reformers promise collective benefits in return. A reformed committee structure, they argue, will better coordinate policymaking. This will reduce policy conflicts, expand information sharing, and lead to better policy outcomes.

Admittedly, public statements do not always accurately reflect underlying motives.

Fortunately, this is an area of study that is conducive to systematic empirical analysis. Bill referrals are regarded as the best indicator of jurisdiction. The "shock" of a reform event can be measured by how it alters existing bill referral patterns. Alternative theories can be tested by comparing the committees than gain and lose issue control through this process, if any.

\section{The Bolling-Hansen Committee Reforms}

At the beginning of the $93^{\text {rd }}$ Congress (1973-74), the House of Representatives established a temporary select committee to consider and recommend changes to its committee structure. The committee's chairman, Richard Bolling (D-MO), described a committee system in "disarray," noting that "it does not facilitate coordinated policies, nor does it coordinate emerging issues, because the jurisdictions of House committees are outdated" (Bolling 1974, 3). Bolling also argued that the turf wars described by King were a central source of this disarray:

When Rule XI [later Rule X] is silent or unclear, the [parliamentarian's] office is guided by precedent, logic or political advantage. Over a period of time such a process inevitably leads to confusion and inconsistency. House committees acquire jurisdiction by accretion. 
Different committees receive similar subject matter. Procedural uncertainty frequently results. Public policy often suffers. (Bolling 1974, 6)

The Bolling committee proposed a comprehensive set of reforms "designed to make the House and its committees, more deliberative, responsive and efficient" (ibid). The recommendations generated immediate and heated opposition, especially among committee chairs (Davidson and Oleszek 1977). After several months, Democratic opponents partly derailed the plan by referring it to a caucus committee chaired by Rep. Julia Butler Hansen (D-WA). The Hansen committee then reported a less ambitious reform package that passed by a vote of 203-165. Among other things, this package included the largest number of jurisdictional changes adopted at one time since the Legislative Reorganization Act of 1946. Did these reforms alter primary responsibility for legislation? If they did, what motivations drove the changes?

We investigate 17 of the 58 changes adopted in 1975 , as well as 10 other jurisdictions unaltered by the reforms (Tables 1 and 2). The 17 altered jurisdictions constitute a stratified sample of the total population of reforms. About two-thirds (11) transfer a jurisdiction from one committee to another, while one-third (6) create new jurisdictions. The sample encompasses a wide variety of committees, including some of the most prestigious (Ways and Means and Commerce), constituency-oriented (Agriculture and Public Works), policy-oriented (Judiciary and Foreign Affairs) and least desired (Post-Office and Standards of Official Conduct). Though small, this sample of jurisdictions includes 25 of Mayhew's "most important" post-war enactments (Mayhew 1991). ${ }^{\text {iii }}$ The 10 unaltered jurisdictions were randomly selected.

The decision to focus on just 27 of the 200 defined jurisdictions in the House rules is a practical one. There is no database of bills categorized by jurisdiction and our study spans seven 
Congresses that produced over 100,000 public bills. As part of a larger project

(www.congressionalbills.org), we have already annotated public bills for subject using the topic system of Baumgartner, Jones and Wilkerson's Policy Agendas Project (www.policyagendas.org). This system divides the entire legislative agenda into 19 major topics and 226 subtopics, where each event is coded as primarily about only one topic and subtopic. It emphasizes intertemporal consistency, so that subtopic activity in one year can be reliably compared to activity in other years. Here, we matched the detailed descriptions of Policy Agendas subtopics to the 27 jurisdiction descriptions found in House Rule X. We then read each bill's title, and culled the ones that did not clearly conform to the jurisdiction. Overall, this study is based on the paths of more than 8000 bill referrals.

[Tables 1 and 2 here]

\section{Reforms and Issue Control in the House}

No study has systematically investigated their effects on which committees have primary control over issues in the form of bill referrals. King's investigation of these reforms, for example, is limited to their impact on the House Commerce committee's jurisdiction, and it does not specifically ask whether the reforms altered which bills were being referred to Commerce. We begin by asking whether the Bolling-Hansen reforms altered referral patterns across multiple committees and jurisdictions. Evidence that they did not will confirm King's (and others') conclusions that the reforms were not important. Evidence that they did will indicate that further investigation of these reforms is warranted.

Hypothesis 1: Path Dependence. The primary purpose of jurisdictional reforms is to formalize existing, informally established referral practices. 
We test this first hypothesis by asking whether bills falling within each of the 27 jurisdictions discussed above were referred to the same committees before (1965-72) and after (1975-1980) the Bolling-Hansen reforms were implemented. More specifically, was the statutory jurisdiction awarded to the committee that received the largest share of referrals before the reform, and did it also receive the lion's share of post-reform referrals?

Figure 1 indicates that newly created issue jurisdictions were almost always awarded to the committee that was already receiving the greatest number of bill referrals. For example, the House Commerce committee received 67 percent of all Biomedical Research and Development referrals prior to 1973. It picked up the newly created jurisdiction in 1975 and subsequently received 100 percent of all Biomedical $R \& D$ referrals (not shown). Similarly, in the 10 "control" jurisdictions that did not change hands, it was also the case that these committees that retained statutory jurisdiction also received most bill referrals before and after the reforms.

[Figure 1 here]

However, in 8 of the 11 cases where a jurisdiction was transferred, it did not go to the committee that had the strongest precedent-based claim. In the majority of these cases, the gaining committee received a very small proportion (less than 20 percent) of all pre-reform referrals. For example, the Government Operations committee did not receive any of the 172 General Revenue Sharing bills introduced and referred prior to 1973 . When statutory control of General Revenue Sharing was transferred to Government Operations (from Ways and Means) in 1975, its share of all bill referrals increased from 0 to 100 percent.

In sum, the patterns for newly created statutory jurisdictions are consistent with what a path dependent account would lead us to expect. Prior bill referral activity predicts which committee will gain the jurisdiction. However, the story for other jurisdictions where statutory control shifted is 
different. In most of these jurisdictions, pre-reform bills referrals do not predict which committee benefits from a transfer, which constitute $2 / 3$ rds of all jurisdictional changes. Clearly, the reforms did more than codify pre-existing patterns of referral activity.

\section{The General Consequences of the Bolling-Hansen Reforms}

Before proceeding to investigate these patterns in more detail, it is worth asking whether the Bolling-Hansen reforms had a general impact on the committee structure. Prior research conceded that some changes occurred but that they had little impact. Reformers, in contrast, argued that the changes would lead to a better organized committee system.

"Entropy" is widely used in the physical sciences and communications to measure level of randomness or disorganization in a system (Shannon and Weaver 1949; Chaffee and Wilson 1977; McCombs and Zhu 1995). More recently, it has been used to study organizations in political science contexts (Talbert and Potowski 2002; Jones et al. 2005). Formally, entropy (H) is defined as:

$$
H=\sum[p(x) \log (p(x))] \equiv-\sum[p(x) \log (p(x))]
$$

Where $x$ represents an object, $p(x)$ is the probability that the object falls within a particular category, summed across all categories. ${ }^{\text {iv }}$ If every object of the same type is found in the same category, then the system is perfectly organized and entropy is 0 . Entropy increases as similar objects are found in different categories, i.e. the system is more disorganized. For example, a system where all red beads are in one jar and all blue beads are in the other jar is better organized (i.e. has lower entropy) than a system where some red beads are located in each jar.

We investigate whether the reforms produced a detectable improvement in committee organization by calculating entropy for referrals of similar bills across committees. Our "objects" 
are referrals of bills within the same Policy Agendas subtopic. Our "categories" are the standing committees. Disorganization (entropy) increases as referrals of bills within the same subtopic are dispersed across more committees. A decline in average entropy (across all 226 subtopics) between the $94^{\text {th }}$ and $95^{\text {th }}$ Congresses would indicate that the Bolling-Hansen reforms concentrated committee control over similar issues.

Figure 2 reports average entropy across the subtopics for each of the $80^{\text {th }}$ to $105^{\text {th }}$ Houses. Entropy declines by $1 / 3 \mathrm{rd}$ or more in the $94^{\text {th }}$ Congress, indicating that the reforms produced a committee structure where control over similar issues was less fragmented. Interestingly, figure 2 also shows a similar (though less dramatic) improvement in organization at the beginning of the $104^{\text {th }}$ Congress, when a new set of reforms were implemented by the newly elected GOP majority.

[Figure 2 here]

A couple of other features of figure 2 warrant discussion. First, the upper line in the figure shows that jurisdictional entropy (fragmentation) is higher when multiple referrals are included. ${ }^{\mathrm{v}}$ This is expected, of course, but it does beg the question of why reformers advanced this second reform that seemed to undermine their broader effort to improve policy coordination. Davidson, Oleszek and Kephart $(1988,5)$ list several motivations, among them that multiple referral serves as a safety valve when complex issues cut across jurisdictional boundaries. Seen in this light, multiple referral is a logical partner to greater consolidation of issue control. Consolidation promotes coordinated policies and leverages existing sources of expertise. But it also raises the risk that important information about a policy's broader consequences will not be considered. The formal option of referring a bill to multiple committees provided a procedural response to the potential informational costs of promoting issue monopolies.

Second, the decline in entropy that coincides with the Bolling-Hansen reforms all but 
disappears just 4 years later. This reversal appears to be an artifact of a rules change in the $97^{\text {th }}$ Congress that allowed for unlimited bill cosponsors (Wilson and Young 1997). The number of bills introduced declines by about $50 \%$ in the $97^{\text {th }}$, partly because legislators had less incentive to introduce identical bills for position-taking reasons. The elimination of duplicate bills of this kind may explain why entropy increased so dramatically in this Congress and subsequently stabilized. The only other spike in entropy occurs in the $91{ }^{\text {st }}$ Congress, when a similar rules change increased the number of allowable cosponsors from 1 to 25 per bill. Regardless, the greatest measured improvements in House jurisdictional organization over the past 60 years coincide with the two formal reforms adopted in the $95^{\text {th }}$ and $104^{\text {th }}$ Congresses.

\section{Intended Consequences}

Existing theories of legislative organization do not provide a compelling explanation for these changes. Political scientists recognize the potential benefits of reform, but question Congress' ability to achieve it. King claims that "jurisdictional arbitration was intentionally taken out of the hands of floor majorities and out of the hands of party leaders" because members could not be trusted to enact reforms that placed collective informational goals ahead of narrower distributive concerns (1997, ch. 4). A leading proponent of the distributive perspective notes that one downside of a committee system organized to serve members' electoral goals is that committee "subunits can get too specialized and jurisdictions too subdivided. Legislative coherence and legislative management suffer as a consequence" (Shepsle 1988, 480).

Nevertheless, reformers claim to be pursuing collective goals: "House Committees should be organized to give coherent consideration to a number of pressing problems whose handling has been fragmented" (House Select Committee on Committees 1974, 1). This explanation leads to an 
interesting insight regarding the tests of the path dependence hypothesis reported earlier. Recall that pre-reform bill referral patterns predicted which committee would gain a new statutory jurisdiction, but could not account for transfers. The reformers' policy coordination perspective also predicts that new statutory jurisdictions will be awarded to the committee receiving the lion's share of prereform referrals, if that committee was also already responsible for closely related issue areas. The committee that is already responsible for closely related issues should also benefit when a jurisdiction is transferred from one committee to another. Path dependence, in contrast, implies that prior referrals will predict all jurisdictional changes, regardless of which committees is primarily responsible for related issues.

Hypothesis 2: Policy Coordination. Formal control of a new or transferred jurisdiction will be awarded to the committee that is most active in closely related policy areas.

Existing research offers other explanations for jurisdictional change, but not as explanations for formal reforms per se (Evans 1999). Here, we frame these explanations to generate predictions about the causes of reform. Jones, Baumgartner and Talbert (1993) argue that a committee's "issue monopoly" persists only as long as other committees allow it. Our earlier finding that committees of jurisdiction control the vast majority of bill referrals supports the notion of issue monopolies. Perhaps controversy or exceptional external interest explains jurisdictional transfers.

Hypothesis 3: Committee Competition. A jurisdiction that is demonstrably contentious is more likely to be transferred. 
Distributive theories of legislative organization portray committee systems as organized to serve members' electoral needs (Shepsle 1978; Shepsle and Weingast 1985; Weingast and Marshall 1988). Scholars have highlighted distributive concerns as the central reason for why reforms fail (King 1997; Adler 2002; Evans 1999). Perhaps the real goal of reform is to consolidate control of issues in the hands of the members whose electoral interests are most affected. No theory has advanced this specific claim, but King does argue that formal reforms "institutionalize logrolls and make it easier to distribute benefits back home" $(1994,48)$.

Hypothesis 4: Electoral Interest. Formal control of a jurisdiction will be awarded to the committee that possesses an extraordinary constituency-based interest in the issue area.

Finally, a more general possibility is that jurisdictional changes benefit the legislators who demonstrate exceptional "interest" in the subject, regardless of motivation. Evans, for example, argues that legislators value issue control because it increases their access to interest group benefits (1999). Perhaps the committees that demonstrate the strongest interest in the subject are the primary beneficiaries of formal reform efforts.

Hypothesis 5: Member Interest. Formal control of a jurisdiction will be awarded to the committee that demonstrates an exceptional interest in the issue area.

\section{Data and Findings}


Our primary hypothesis is that the main intent and effect of jurisdictional reform is to unify control over "closely related" issues. We define bills to be "related" if they fall within the same Policy Agendas subtopic(s). ${ }^{\text {vi }}$ Thus, the central expectation is that a newly created or transferred jurisdiction will be assigned to the committee that is already receiving most of the referrals of other bills falling within the same subtopic.

Table 3 offers strong support for this hypothesis. ${ }^{\text {vii }}$ Every newly created jurisdiction and 8 of the 10 transferred jurisdictions were awarded to these committees. This same pattern holds for the stable jurisdictions; in 8 of the 11 cases, the committee of jurisdiction was also primarily responsible for closely related issue areas. ${ }^{\text {viii }}$

[Table 3 and 4 here]

The claim that the intent and effect of the Bolling-Hansen reforms was to reduce issue fragmentation and better coordinate policymaking receives considerable support in these data. However, it is worth considering whether alternative explanations can better account for this pattern. One possibility is that the changes were driven by committee competition (Hypothesis 3 ). Jones, Baumgartner and Talbert (1993) and others define issue competition in terms of which committees are holding hearings in an issue area, whether they possess statutory jurisdiction or not. We apply their metric, the Herfindahl concentration score, to test whether the reformed jurisdictions in this study were more contentious than the unaltered ones. Herfindahl scores have a theoretical range between 0 and 1, where 1 indicates that a single committee held all of the hearings in an issue area, .5 indicates that two committees were holding the same number of hearings, and values close to 0 indicate that many committees were equally active in holding hearings.

The question of interest is whether reformed jurisdictions were unusually contentious compared to jurisdictions that were not reformed. The unaltered jurisdictions constitute the baseline 
(Table 5). Here, the Herfindahl scores for pre-reform hearings average .74, indicating highly concentrated activity. Pre-reform bill referral activity is even more highly concentrated (.87). Hypothesis 3 predicts that reformed jurisdictions will have substantially lower Herfindahl scores. However, for transferred jurisdictions, the average Herfindahls are very similar to those reported for unaltered jurisdictions (.69 and .84 respectively). Only pre-reform bill referrals in newly created jurisdictions are substantially less concentrated (.57). Thus, committee competition may help to explain why statutory jurisdictions are created in the first place, but it does not appear to explain why jurisdictions are transferred from one committee to another.

[Table 5 here]

A related possibility is that reforms concentrate issue control in the hands of the most interested lawmakers (Hypotheses 4 and 5). This could explain why reforms bring similar issues under the same committee umbrella, but without challenging existing distributive accounts. To investigate this possibility, we first ask if the gaining committee is an "interest-outlier" relative to the chamber. Specifically, is the median level of constituency interest (e.g. percent of population living in rural farm areas) in the jurisdiction (e.g. agricultural commodities) in the gaining committee significantly greater than the median level of interest among all other non-committee members? This can be a more difficult test than simply asking whether the gaining committee was more interested than the losing one (Groseclose 1994; Adler and Lapinski 1997).

[Table 6 here]

Our measures of constituency interest come primarily from Adler's Congressional District Data Project. Not all of the jurisdictions correspond to measurable constituency interests (e.g. Consumer Protection). For this reason, we are only able to test the $4^{\text {th }}$ hypothesis for 9 of the 17 reformed jurisdictions (Table 6). In only 3 out of these 9 was the gaining committee a clear interest outlier. In two of the remaining 6 cases (International Commodities and Urban Mass Transit), the 
most interested committee lost the jurisdiction. Thus, constituency-based motivations may explain why reform efforts sometimes fail (Adler 2002), but they do not appear to explain the changes that are adopted.

A final possibility is that reforms reward interest that is not constituency-driven. Here we measure committee interest in terms of bill sponsorship, by regressing the number of bills that each committee member sponsored in the issue area pre-reform against whether he or she was a member of the committee that later gained the jurisdiction. ${ }^{\text {ix }}$ A positive coefficient is interpreted as indicating that the gaining committee's members demonstrated above average interest in the issue area in advance of the reforms. Table 7 indicates that this was the case for newly created jurisdictions, but was not true for the more common cases of transfers. In only 3 of these 11 cases were the gaining committee's members significantly more active sponsors. ${ }^{\mathrm{x}}$

[Table 7 here]

Taken together, these findings offer little support for the notion that jurisdictional reforms benefit the most interested legislators. Altered jurisdictions were not more highly contested during the pre-reform era, nor did the gaining committees' members demonstrate exceptional interest. In the minority of cases involving newly created jurisdictions, there is limited support for the competition and interest hypotheses. However, it was also true that the gaining committees in these cases also possessed jurisdiction over closely related issues. Clearly, a multivariate approach to sorting out these potential explanations is warranted.

\section{Motivations for Reform: A Multivariate Approach}

This final section shifts the focus away from the awarding of formal jurisdiction to predicting a standing committee's share of post-reform bill referrals within each jurisdiction. Thus, the 
dependent variable is the proportion of bills in a jurisdiction that are referred to a particular committee, for all 20 committees (except Budget and Rules) and all 27 jurisdictions in our sample $(n=540)$. Budget and Rules are excluded because these panels have narrow jurisdictions and do not normally consider regular legislation. The independent variables are the same ones that were applied earlier: pre-reform bill referrals (path dependence), pre-reform hearings activity (committee competition), pre-reform bill sponsorship (member interest), and pre-reform referrals of closely related bills (policy coordination).

Which explanations best predict a committee's share of post-reform referrals? Table 8 reports results for an OLS multivariate regression model with robust standard errors. ${ }^{\mathrm{xi}}$ Only two of the independent variable coefficients are significant and in the correct direction - those for prereform hearings activity within the jurisdiction and pre-reform referrals in closely related issue areas. These findings offer initial support for the committee competition and issue unification hypotheses. However, due to multicollinearity, the coefficients may not be robust to alternative specifications. $^{\text {xii }}$

[Tables 8 and 9 here]

We conduct two follow-up tests. An extreme-bounds analysis (EBA) assesses the fragility of each independent variable's effect to the inclusion of other variables into the model (Leamer 1983, Levine and Renelt 1992). Table 9 indicates that the same two variables (pre-reform hearings in the jurisdiction and pre-reform bill referrals in closely related jurisdictions) are robust predictors of post-reform referrals. Pre-reform bill referrals and sponsorship activity within the jurisdiction do not consistently predict post-reform referrals.

Finally, the J-test (sometimes referred to as the Cox test) of variance encompassing can be 
used to test whether a rival variable retains any explanatory power in a model that includes the variable of interest (Greene 2002; Granato and Suzuki 1996). Pairing each of the independent variables against one another (analysis not shown) revealed that only the policy coordination explanation (pre-reform referrals of closely related bills) encompasses all of the other explanations. That is, the other independent variables do not add explanatory power after we control for explanatory power of this single variable.

\section{Discussion}

A thriving body of empirical research tests theories of committee power, but little of this research examines how issue jurisdictions get allocated among committees and why. The limited research that does focus on jurisdictions devotes little attention to the intent and consequences of formal reforms. We find that the Bolling-Hansen reforms of 1975 substantially altered committee control over issues in the House of Representatives. Within specific issue areas and across the committee system as a whole, authority over related policy areas became more coherent and less fragmented. These findings challenge widely held notions that formal reforms, including the one examined here, have little impact on issue control in the House.

We have tested several explanations for the changes detected and found most of them wanting. The reforms did not benefit the most interested legislators, based on their prior sponsorship activity or constituency characteristics. They did not simply enforce precedent by formalizing existing bill referral practices. The explanation that receives the greatest support is the one reformers offered - to unify control over related issues for the purpose of improving policy coordination and enhancing information sharing. 
These findings do not demonstrate that reforms always succeed, or that jurisdictions always end up in the hands of the most qualified committees. They do not undermine much of what King $(1994,1997)$ discovered in his careful examination of House Commerce committee politics. It is true that committees compete for turf, and that the parliamentarian is guided by precedent in cases where Rule X offers limited guidance. A committee that has a track record of activity in an issue area possesses expertise that may benefit the broader legislature. However, informal practices such as these can set in motion a path dependent process that can undermine other policy objectives. Formal reforms are the antidote, and in contrast to King, we have found that legislators are willing to consider their use for these purposes.

Reform debates often center on legitimate differences of opinion about which jurisdictional arrangements best serve the needs of the legislature. On the one hand, preserving existing jurisdictional arrangements may be the best way to preserve expertise. Over the long run, however, such practices can lead to issue fragmentation, conflicting policies, and inefficient information sharing. Whereas prior studies have highlighted political considerations that discourage change, our findings demonstrate that legislators recognize the downside of such dynamics and have acted to counteract them.

Mayhew has argued that deductive models that portray legislators as agents or instruments of interests and preferences ignore key aspects of congressional politics $(2000, x){ }^{x i i i}$ In our view, congressional reforms have received less attention than they deserve for similar reasons. Prior empirical studies of reform have tended to focus on the controversy that reforms induce, while devoting less attention to systematically examining their effects (Davidson and Oleszek 1977; Sheppard 1985; Evans and Oleszek 1997; Reiselbach 1994; Adler 2002; Wolfensberger 2004). Although the most ambitious plans are often swept aside, scholars have been too quick to conclude 
that little was therefore accomplished. By considering the stated aims of reform advocates we may be able to gain new insights into the motivations and effects of such collectively-oriented changes. 


\section{Bibliography}

Adler, E. Scott. 2002. Why Congressional Reforms Fail: Reelection and the House Committee System. Chicago: University of Chicago Press.

Adler, E. Scott, and John Lapinski. 1997. "Demand-side Theory and Congressional Committee Composition: A Constituency Characteristics Approach.” American Journal of Political Science 41 (July): 895-918.

Baumgartner, Frank, and Bryan Jones. 1991. “Agenda Dynamics and Policy Subsystems.” Journal of Politics 53 (November):1044-74.

Baumgartner, Frank, and Bryan Jones. 1993. Agendas and Instability in American Politics. Chicago: University of Chicago Press.

Baumgartner, Frank, Bryan Jones, and Michael MacLeod. 2000. "The Evolution of Legislative Jurisdictions." Journal of Politics 62 (Spring):321-349.

Becker, Lawrence. 2005. Doing The Right Thing: Collective Action And Procedural Choice In The New Legislative Process. Ohio State University Press

Bolling, Richard. 1974. "Congress and Its Committee System.” Annals of the American Academy of Political and Social Science. 411 (Winter):1-14.

Chafee, Steven H., and Donna G. Wilson. 1977. "Media Rich, Media Poor: Two Studies of Diversity in Agenda Holding.” Journalism Quarterly 54 (Fall): 466-76.

Cohen, Richard, Siobhan Gorman, and Sydney Freedberg. 2003. "The Ultimate Turf War." National Journal, January 4, 16-23.

Congressional Quarterly Weekly Report (various editions). Washington DC: Congressional Quarterly Inc. 
Cooper, Joseph. 1970. The Origin of the Standing Committees and the Development of the Modern House. Houston: Rice University.

Cox, Gary and Matthew McCubbins. 1994. Legislative Leviathan: Party Government in the House. Berkeley: University of California Press.

Davidson, Roger, and Walter Oleszek. 1977. Congress Against Itself. Bloomington: Indiana University Press.

Davidson Roger and Walter Oleszek. 2004. Congress and Its Members. $9^{\text {th }}$ Edition. Washington DC: Congressional Quarterly Press.

Davidson, Roger H, Walter J. Oleszek and Thomas Kephart. 1988. “One Bill, Many Committees: Multiple Referrals in the U. S. House of Representatives" Legislative Studies Quarterly. 13 (Winter): 3-28.

Deering, Christopher, and Steven Smith. 1997. Committees in Congress. 3rd ed. Washington, D.C.: Congressional Quarterly.

Eilperin, Juliet and Michael Grunwald. 2007. "Internal Rifts Cloud Democrats' Opportunity on Warming," The Washington Post, January 23.

Evans, C. Lawrence and Walter J. Oleszek. 1997. Congress Under Fire: Reform Politics and the Republican Majority. Houghton Mifflin Company

Evans, C. Lawrence. 1999. “Legislative Structure: Rules, Precedents, and Jurisdictions.” Legislative Studies Quarterly 24 (November):605-42.

Fenno, Richard. 1973. Congressmen in Committees. Boston: Little, Brown and Co.

Gamm, Gerald, and Kenneth Shepsle. 1988. "Emergence of Legislative Institutions: Standing Committees in the House and Senate, 1810-25." Legislative Studies Quarterly 15 (February): 39-66. 
Gilligan, Thomas W., and Keith Krehbiel. 1990. "Organization of Informative Committees by a Rational Legislature.” American Journal of Political Science 34 (May): 531-64.

Granato, Jim and Motoshi Suzuki. 1996. "The Use of the Encompassing Principle to Resolve Empirical Controversies in Voting Behavior: An Application to Voter Sophistication in Congressional Elections.” Electoral Studies 15 (August): 383-398.

Greene, William. 2002 Econometric Analysis. Upper Saddle River, N.J.: Prentice-Hall.

Groseclose, Tim. 1994. "The Committee Outlier Debate: A Review and a Reexamination of Some of the Evidence." Public Choice 80 (September):265-73.

Hardin, John W. 1998a. “Advocacy versus Certainty: The Dynamics of Committee Jurisdiction Concentration," Journal of Politics 60 (May): 374-397.

Hardin, John W. 1998b. "An In Depth Look at Congressional Committee Jurisdictions Surrounding Health Issues." Journal of Health Politics, Policy and Law. 23 (Summer): 517-50

House Select Committee on Committees. 1974. Monographs on the Committees of the House of Representatives. $93^{\text {rd }}$ Congress, $2^{\text {nd }}$ Session. Washington DC: Government Printing Office. Jones, Bryan, Frank Baumgartner, and Jeffrey Talbert. 1993. “The Destruction of Issue Monopolies in Congress." American Political Science Review 87 (September):657-71.

King, David. 1994. “The Nature of Congressional Committee Jurisdictions.” American Political Science Review 88 (March):48-62.

King, David. 1997. Turf Wars: How Congressional Committees Claim Jurisdictions. Chicago: University of Chicago Press.

Khrebiel, Keith. 1991. Information and Legislative Organization. Ann Arbor: University of Michigan Press.

Leamer, E.E. 1983. "Let's Take the Con Out of Econometrics." American Economic Review 73 
(March):31-43.

Levine, R. and Renelt, D. 1992. "A Sensitivity Analysis of Cross-Country Growth Regressions." The American Economic Review 82 (Fall): 942-963.

Maltzman, Forrest. 1997. Competing Principals: Committees, Parties, and the Organization of

Congress. Ann Arbor: University of Michigan Press.

Mayhew, David. 1974. Congress: The Electoral Connection. New Haven: Yale University Press

Mayhew, David. 2000. America's Congress: Actions in the Public Sphere James Madison through

Newt Gingrich. New Haven: Yale University Press.

McCombs, Maxwell, and Jian-Hua Zhu. 1995. "Capacity, Diversity, and Volatility of the Public

Agenda: Trends from 1954 to 1994.” Public Opinion Quarterly 59: 495-525.

Nather, David, and Karen Foerstel. 2002. "Proposal Presages Turf Wars." Congressional Quarterly Weekly Report, June 8, 1505.

National Commission on Terrorist Attacks Upon the United States. 2004. The 9/11 Commission

Report: Final Report of the National Commission on Terrorist Attacks Upon the United States.

NY: WW Norton

Oleszek, Walter. 2003. Congressional Procedures and the Policy Process. Washington D.C.:

Congressional Quarterly.

Parker, Glenn. 1996. Congress and the Rent Seeking Society. Ann Arbor: University of Michigan Press

Rieselbach, Leroy. 1994. Congressional Reform: The Changing Modern Congress. Washington, D.C.: Congressional Quarterly.

Schickler, Eric, and Andrew Rich. 1997. "Controlling the Floor: Parties as Procedural Coalitions in the House." American Journal of Political Science 41 (October):1340-75. 
Shannon, Claude, and Weaver, Mayiam. 1971. The Mathematical Theory of Communication.

Urbana, Ill.: University of Illinois Press.

Sheppard, Burton. 1985. Rethinking Congressional Reform: The Reform Roots of the Special

Interest Congress. Cambridge: Schenkman Books

Shepsle, Kenneth. 1978. The Giant Jigsaw Puzzle. Chicago: University of Chicago Press.

Shepsle, Kenneth, and Barry Weingast. 1987. "The Institutional Foundations of Committee Power." American Political Science Review 81 (March): 85-104.

Shepsle, Kenneth. 1988. "Representation and Governance: The Great Legislative Tradeoff." Political Science Quarterly 103 (3): 461-84.

Stewart, Charles III. 1989. Budget Reform Politics: The Design of the Appropriations Process in the House of Representatives, 1865-1921. NY: Cambridge University Press.

Talbert, Jeffrey, and Matthew Potoski. 2002. "The Capacity, Complexity and Volatility of the House Agenda" in Policy Dynamics, Frank Baumgartner and Bryan Jones, eds. Chicago: University of Chicago Press.

Tiefer, Charles. 1989. Congressional Practice and Procedure. Greenwood.

Waterman, Shaun. 2005. "New Homeland Security Committee Off to Shaky Start" Washington Times. January 4, 2005.

Weingast, Barry and William Marshall. 1988. "The Industrial Organization of Congress; or, Why Legislatures, Like Firms, Are Not Organized as Markets." Journal of Political Economy. 96 (1): 132-63.

Weisman, Jonathan. 2007. “Emerging Greivances Within Party Likely to Test Pelosi,” The Washington Post, January 22. 
Wilkerson, John D., E. Scott Adler, T. Jens Feeley. 2003. "Committees, Credit Claiming and Legislative Effectiveness in the House: 1973-1998" Paper presented at the 2003 Annual Meeting of the American Political Science Association, Philadelphia PA

Wilson, Rick and Cheryl Young. 1997. "Cosponsorship in the U.S. Congress.” Legislative Studies Quarterly. 22 (February): 25-43.

Wolfensberger, Donald R. "Reorganizing Congress and the Executive in Response to Focusing Events. Lessons of the Past, Portents of the Future." Paper presented at the 2004 Southern Political Science Association Meetings, New Orleans, LA Jan. 8-10, 2004

Young, Gary and Joseph Cooper. 1993. "Multiple Referral and the Transformation of House Decision Making." In Congress Reconsidered, $4^{\text {th }}$ ed. Lawrence C. Dodd and Bruce R. Oppenheimer, eds. Washington D.C.: CQ Press. 211-34. 
Table 1. Formal Changes in House Committee Jurisdictions Examined

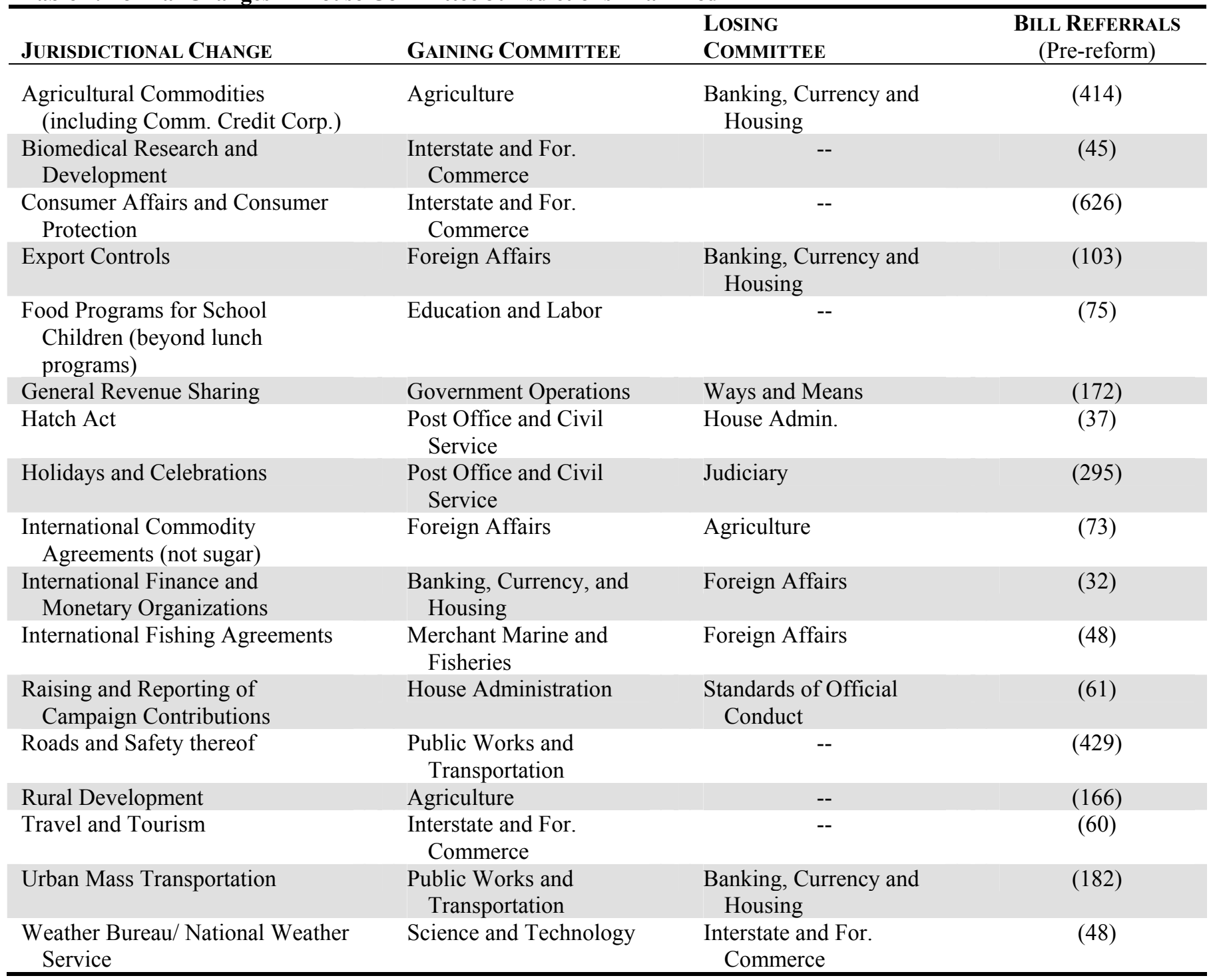

"Gaining committees" are those committees that formally acquire a jurisdiction either through transfer from another panel or assignment of a newly created jurisdiction. "Losing committees" are those giving up a jurisdiction in a transfer. Dashes represent instances of newly created jurisdictions. 


\begin{tabular}{|c|c|c|}
\hline JURISDICTION & COMMITTEE OF JURISDICTION & $\begin{array}{l}\text { RELEVANT BILL REFERRALS } \\
\text { (Pre-reform) }\end{array}$ \\
\hline $\begin{array}{l}\text { Adulteration of Seeds, Insect Pests, and } \\
\text { Protection of Birds and Animals in Forest } \\
\text { Reserves }\end{array}$ & Agriculture & (8) \\
\hline Human Nutrition and Home Economics & Agriculture & (29) \\
\hline $\begin{array}{l}\text { Regulation of Common Carriers by Water } \\
\text { (except matters subject to the jurisdiction } \\
\text { of the Interstate Commerce Commission) } \\
\text { and Inspection of Merchant Marine } \\
\text { Vessels, Lights and Signals, Lifesaving } \\
\text { Equipment, and Fire Protection on Such } \\
\text { Vessels }\end{array}$ & Merchant Marine and Fisheries & (99) \\
\hline $\begin{array}{l}\text { Municipal Code and Amendments to the } \\
\text { Criminal and Corporation Laws in DC }\end{array}$ & District of Columbia & (89) \\
\hline Municipal and Juvenile Courts in DC & District of Columbia & (9) \\
\hline National Science Foundation & Science & $(108)$ \\
\hline $\begin{array}{l}\text { Preservation of Prehistoric Ruins and Objects } \\
\text { of Interest on the Public Domain }\end{array}$ & Interior and Insular Affairs & $(242)$ \\
\hline Rural Electrification & Agriculture & (53) \\
\hline $\begin{array}{l}\text { Status of Officers and Employees of the United } \\
\text { States, Including Their Compensation, } \\
\text { Classification, and Retirement }\end{array}$ & Post Office and Civil Service & $(1701)$ \\
\hline Wages and Hours of Labor & Education and Labor & (115) \\
\hline
\end{tabular}

Stable jurisdictions were those that were not changed at all during the Bolling/Hansen reforms. 
Table 3: Committee "Expertise" in Transferred and New Jurisdictions,

Pre-reform (1965-1972)

\begin{tabular}{|c|c|c|c|c|c|}
\hline $\begin{array}{l}\text { Jurisdiction } \\
\text { (Gaining Committee) }\end{array}$ & $\begin{array}{l}\text { Closely } \\
\text { related } \\
\text { bills } \\
\text { referred to } \\
\text { gaining } \\
\text { comm. } \\
\end{array}$ & $\begin{array}{c}\text { Closely } \\
\text { related bills } \\
\text { referred to } \\
\text { losing } \\
\text { comm. } \\
\end{array}$ & $\begin{array}{l}\text { Next most } \\
\text { expert } \\
\text { committee }\end{array}$ & $\begin{array}{c}\text { Closely } \\
\text { related bills } \\
\text { referred to } \\
\text { next most } \\
\text { expert } \\
\text { comm. }\end{array}$ & $\begin{array}{l}\text { Number of } \\
\text { bills } \\
\text { "closely } \\
\text { related" to } \\
\text { jurisdiction }\end{array}$ \\
\hline \multicolumn{6}{|c|}{ Transferred Jurisdictions } \\
\hline Commodities (Agric) & .89 & .05 & Jud & .08 & 483 \\
\hline $\begin{array}{l}\text { Campaign Contributions } \\
\text { (House Admin) }\end{array}$ & .51 & .01 & Jud & .26 & 339 \\
\hline $\begin{array}{l}\text { Export Controls } \\
\text { (For Affs) }\end{array}$ & .36 & .01 & WM & .27 & 136 \\
\hline $\begin{array}{l}\text { Gen Revenue Sharing } \\
\text { (Govt Ops) }\end{array}$ & .30 & .15 & Jud & .19 & 346 \\
\hline Hatch Act (Post Office) & .66 & .07 & WM & .07 & 2270 \\
\hline Holidays (Post Office) & -- & -- & -- & -- & -- \\
\hline $\begin{array}{l}\text { Intl Commodity Agrmts } \\
\text { (For Affs) }\end{array}$ & .00 & .96 & Commerce & .03 & 224 \\
\hline $\begin{array}{l}\text { Intl Fin. \& Monetary } \\
\text { Orgs (Banking) }\end{array}$ & .83 & .02 & WM & .09 & 545 \\
\hline $\begin{array}{l}\text { Intl Fishing Agreements } \\
\text { (Merch Marine) }\end{array}$ & .80 & .00 & PW & .07 & 1020 \\
\hline $\begin{array}{l}\text { Urban Mass Transit } \\
\text { (Public Works) }\end{array}$ & .00 & .29 & Bank & .71 & 38 \\
\hline Weather (Science) & .69 & .09 & MMF & .13 & 159 \\
\hline Mean & .50 & .17 & & .19 & \\
\hline \multicolumn{6}{|l|}{ New Jurisdictions } \\
\hline $\begin{array}{r}\text { Biomed R\&D } \\
(\text { Commerce })\end{array}$ & .65 & -- & WM & .12 & 696 \\
\hline $\begin{array}{l}\text { Consumer protection } \\
(\text { Commerce })\end{array}$ & .50 & - & WM & .29 & 66 \\
\hline $\begin{array}{l}\text { Food for School } \\
\text { Children }(E d \& \\
\text { Labor })\end{array}$ & .56 & - & WM & .20 & 578 \\
\hline $\begin{array}{l}\text { Road Safety (Public } \\
\text { Works) }\end{array}$ & .60 & -- & WM & .12 & 197 \\
\hline Rural Devel (Agric) & -- & -- & -- & -- & -- \\
\hline Tourism (Commerce) & -- & -- & -- & -- & -- \\
\hline Mean & .58 & & & .18 & \\
\hline
\end{tabular}

Cells in columns 2, 3, and 5 represent proportion of total number of "closely related" bills to each jurisdiction. $\mathrm{WM}=$ Ways and Means; Jud = Judiciary, $\mathrm{PW}=$ Public Works; and Bank = Banking, Currency and Housing, MMF $=$ Merchant Marine and Fisheries. 
Table 4: Committee "Expertise" in Stable Jurisdictions, Pre-reform (19651972)

\begin{tabular}{|c|c|c|}
\hline $\begin{array}{l}\text { Jurisdiction } \\
\text { (Committee) }\end{array}$ & $\begin{array}{l}\text { Closely related bills } \\
\text { referred to comm. }\end{array}$ & $\begin{array}{l}\text { Number of bills closely } \\
\text { related to jurisdiction }\end{array}$ \\
\hline $\begin{array}{l}\text { Adulteration of Seeds } \\
\text { (Agric) }\end{array}$ & .74 & 199 \\
\hline $\begin{array}{l}\text { Human Nutrition } \\
\text { (Agric) }\end{array}$ & .50 & 156 \\
\hline $\begin{array}{l}\text { Common Carriers } \\
\text { (Merchant Marine) }\end{array}$ & .83 & 978 \\
\hline $\begin{array}{l}\text { Municipal Code in D.C. } \\
(D C)\end{array}$ & .84 & 1061 \\
\hline $\begin{array}{l}\text { Municipal/Juvenile } \\
\text { Courts in D.C. }(D C)\end{array}$ & .85 & 1144 \\
\hline $\begin{array}{l}\text { Natl Science } \\
\text { Foundation (Science) }\end{array}$ & .21 & 29 \\
\hline $\begin{array}{l}\text { Preservation of Ruins } \\
\text { (Interior) }\end{array}$ & .78 & 914 \\
\hline $\begin{array}{l}\text { Collisions at Sea } \\
\text { (Merchant Marine) }\end{array}$ & -- & -- \\
\hline $\begin{array}{l}\text { Rural Electrification } \\
\text { (Agric) }\end{array}$ & .00 & 140 \\
\hline $\begin{array}{l}\text { Fed. Employee } \\
\text { Compen. (Post Office) }\end{array}$ & .68 & 1992 \\
\hline $\begin{array}{l}\text { Wages and House of } \\
\text { Labor }(E d \& \text { Labor) }\end{array}$ & .90 & 80 \\
\hline Mean & .63 & \\
\hline
\end{tabular}

Cells represent proportion of total number of "closely related" bills to each jurisdiction. 
Table 5. Herfindahl Scores for Hearings Activity and Bill Referrals in House Committee Jurisdictions, Prereform (1965-72)

\begin{tabular}{|c|c|c|c|}
\hline & $\begin{array}{c}\text { HERFINDAHL } \\
\text { SCORES FOR BILL } \\
\text { REFERRALS } \\
\end{array}$ & $\begin{array}{c}\text { HERFINDAHL SCORE } \\
\text { FOR DAYS OF } \\
\text { HEARINGS } \\
\end{array}$ & $\begin{array}{c}\text { TOTAL DAYS OF } \\
\text { HEARINGS } \\
\end{array}$ \\
\hline \multicolumn{4}{|l|}{ Stable Jurisdictions } \\
\hline Adulterate Seeds/Protect Bird & 1.00 & .76 & 22 \\
\hline Municipal/Juv. Courts in DC & 1.00 & 1.00 & 26 \\
\hline Rural Electrification & 1.00 & .68 & 21 \\
\hline National Science Foundation & .98 & .94 & 60 \\
\hline Fed Employees Compen. & .96 & .67 & 360 \\
\hline Municipal Code in DC & .94 & .65 & 171 \\
\hline Preservation of Ruins/Objects & .89 & .52 & 19 \\
\hline Common Carriers by Water & .79 & 1.00 & 19 \\
\hline Wages and Hours of Labor & .79 & .68 & 66 \\
\hline Human Nutrition & .39 & .51 & 27 \\
\hline $\begin{array}{l}\text { table Jurisdictions } \\
\text { Mean }\end{array}$ & .87 & .74 & \\
\hline \multicolumn{4}{|l|}{ Transferred Jurisdictions } \\
\hline Intl Fishing Agreements & 1.00 & .86 & 13 \\
\hline General Revenue Sharing & .99 & .67 & 19 \\
\hline Holidays and Celebrations & .98 & 1.00 & 4 \\
\hline Agricultural Commodities & 97 & .91 & 87 \\
\hline Hatch Act & .90 & -- & 0 \\
\hline Export Controls & .82 & 1.00 & 24 \\
\hline Weather Service & .75 & .63 & 4 \\
\hline Intl Finance/Monetary Orgs & .72 & .37 & 55 \\
\hline Urban Mass Transportation & .72 & .51 & 22 \\
\hline Intl Commodity Agreements & .70 & .40 & 34 \\
\hline Raising Campaign Contrib. & .52 & .51 & 9 \\
\hline & .82 & .69 & \\
\hline \multicolumn{4}{|l|}{ Transferred Juris. Mean } \\
\hline \multicolumn{4}{|l|}{ New Jurisdictions } \\
\hline Roads and Safety & .82 & 1.00 & 46 \\
\hline Food Programs for Children & .77 & .53 & 13 \\
\hline Biomedical R\&D & .50 & 1.00 & 29 \\
\hline Travel and Tourism & .50 & 1.00 & 6 \\
\hline Consumer Protection & .42 & .42 & 123 \\
\hline Rural Development & .41 & .85 & 42 \\
\hline & .57 & .80 & \\
\hline \multicolumn{4}{|l|}{ ew Jurisdictions Mean } \\
\hline F-test Stable vs. Transferred & $.455(\mathrm{p}=0.835)$ & $.421(\mathrm{p}=0.837)$ & \\
\hline F-test New vs. Transferred & $122.4(\mathrm{p}=0.068)$ & $7.90(p=0.114)$ & \\
\hline
\end{tabular}

The Herfindahl index is the sum of the squared proportions of each jurisdiction's hearings or bill referrals by committee [Herfindahl index $\left.=\left(S_{1}\right)^{2}+\left(S_{2}\right)^{2}+\left(S_{3}\right)^{2}+\ldots+\left(S_{\mathrm{n}}\right)^{2}\right]$. Herf scores approaching 0 indicate that activity is more dispersed across committees (more competition), while Herf scores approaching 1 indicate less dispersed activity (less competition). 
Table 6. Constituency Interests for Committees Involved in Jurisdictional Changes,

93rd Congresses

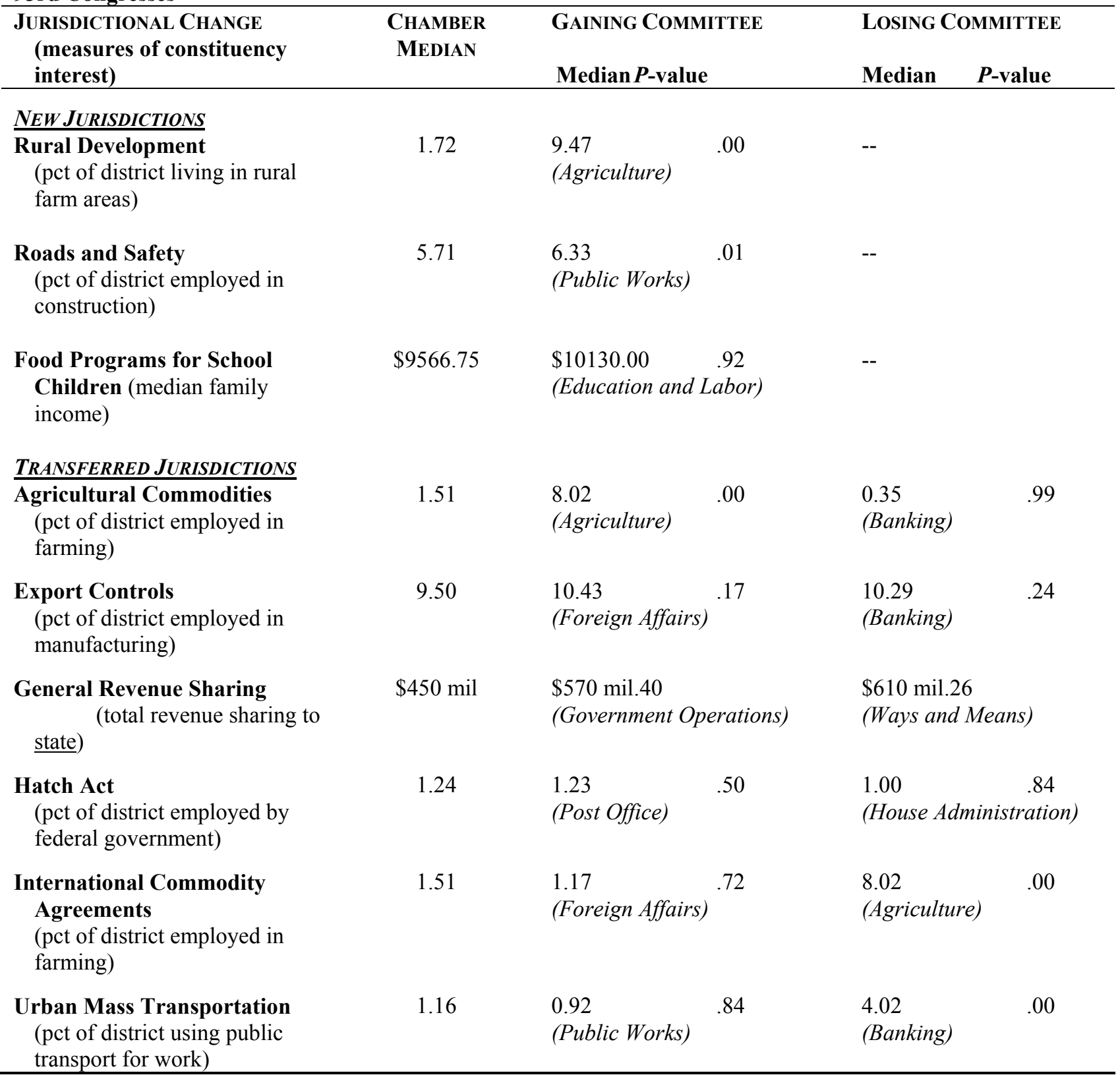
transport for work)

All analyses are Monte Carlo difference-in-medians test (see Adler and Lapinski 1997; Groseclose 1994), except General Revenue Sharing (GRS). GRS is a Wilcoxon rank sum test because of the use of state-level data. 
Table 7: Committee "Interest" in Jurisdictional Arenas, 1965-1972

\section{MEAN BILLS \\ SPONSORED BY \\ ENTIRE CHAMBER}

\section{MARGINAL EFFECT OF \\ MEMBERSHIP ON GAINING \\ COMMITTEE}

P-VALUE

\section{New Jurisdictions}

Consumer Protection

Food Programs for Children

Roads and Safety

Rural Development

Biomedical R\&D

Travel and Tourism
1.06

0.13

0.57

0.34

0.07

0.10

0.54

0.05

0.28

0.07

0.05

0.07

0.43

0.10

0.13

0.07

0.23
2.50

0.60

1.53

1.15

0.21

0.22

1.84

0.51

$-0.08$

0.25

0.15

0.15

0.64

0.20

0.20

0.13

0.18
0.00

0.00

0.00

0.00

0.04

0.09

0.00

0.00

0.00

0.01

0.16

0.16

0.17

0.21

0.34

0.35

0.52

General Revenue Sharing

"Mean bills sponsored" is the average number of bills sponsored per member of the $93^{\text {rd }}$ Congress in each jurisdiction for the eight years prior to the reforms. The "marginal effect" coefficient is generated by regressing (using a Poisson distribution) the number of jurisdiction-specific bills that every legislator sponsored in the same period on whether or not s/he was a member of the committee that subsequently gained the jurisdiction. 
Table 8: OLS Regression of Post-reform Bill Referrals on Pre-reform Jurisdictional Factors

\begin{tabular}{|l|c|c|c|}
\hline & Coefficient & Std. Err. & p-value \\
\hline Pre-reform bill referrals & 0.114 & 0.109 & 0.296 \\
\hline $\begin{array}{c}\text { Pre-reform bill } \\
\text { sponsorship }\end{array}$ & 0.116 & 0.097 & 0.232 \\
\hline $\begin{array}{c}\text { Pre-reform hearings } \\
\text { activity }\end{array}$ & 0.263 & 0.113 & 0.020 \\
\hline & & & 0.000 \\
\hline $\begin{array}{c}\text { Pre-reform referral of } \\
\text { "close by" bills }\end{array}$ & 0.615 & 0.123 & \\
\hline & 0.015 & 0.037 & 0.696 \\
\hline Constant & 540 & & \\
\hline N & 0.733 & & \\
\hline R-squared & & & \\
\hline & & & \\
\hline
\end{tabular}

Table 9: Extreme-bounds Analysis for Explanations of Post-reform Bill Control

\begin{tabular}{|c|c|c|c|c|}
\hline Variable & $\begin{array}{l}\text { Min. Value } \\
\text { (S.E.) }\end{array}$ & $\begin{array}{c}\text { Max. Value } \\
\text { (S.E.) }\end{array}$ & Avg. Value & $\begin{array}{c}\text { Proportion } \\
\text { significant } \\
(p<.05)\end{array}$ \\
\hline Pre-reform bill referrals & $\begin{array}{c}0.114 \\
(0.109)\end{array}$ & $\begin{array}{c}0.637 \\
(0.080)\end{array}$ & 0.291 & 0.5 \\
\hline Pre-reform bill sponsorship & $\begin{array}{l}0.116 \\
(0.097)\end{array}$ & $\begin{array}{c}1.181 \\
(0.120)\end{array}$ & 0.411 & 0.63 \\
\hline Pre-reform hearings activity & $\begin{array}{c}0.263 \\
(0.113) \\
\end{array}$ & $\begin{array}{c}0.710 \\
(0.078) \\
\end{array}$ & 0.432 & 1.00 \\
\hline $\begin{array}{l}\text { Pre-reform referral of } \\
\text { "close by" bills }\end{array}$ & $\begin{array}{l}0.615 \\
(0.1240\end{array}$ & $\begin{array}{l}1.027 \\
0.076\end{array}$ & 0.741 & 1.00 \\
\hline
\end{tabular}




\section{Figure 1. Pre-reform Bill Referrals to the Committee Awarded Jurisdiction (1965-1972)}

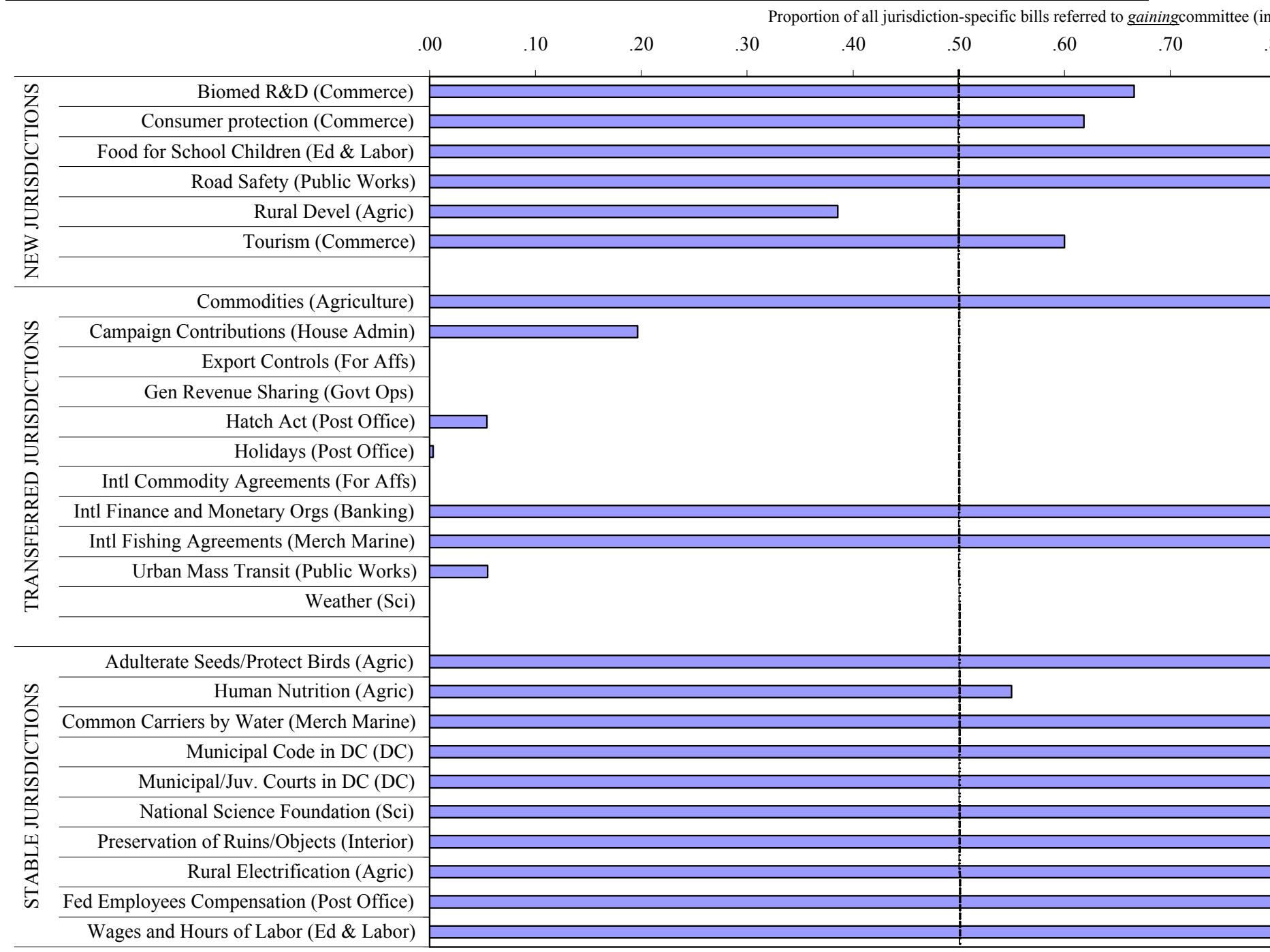


Figure 2. Entropy of Related Bill Referrals to House Committees (1947-98)

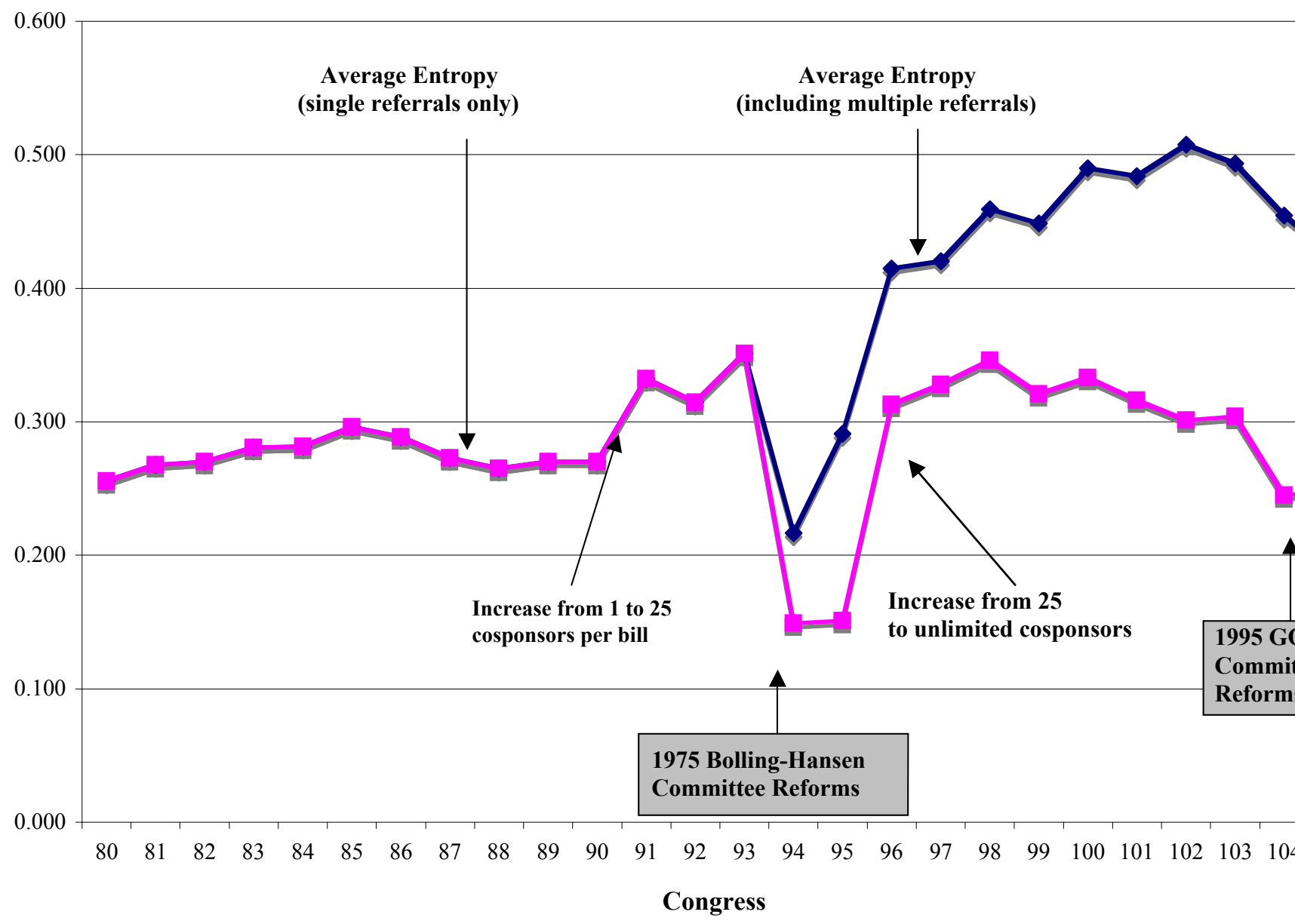




\section{$\underline{\text { Endnotes }}$}

${ }^{\mathrm{i}}$ Rep. Bill Frenzel (R-MN), Congressional Record, September 30, 1974, 33004. Frenzel was speaking in favor of the Bolling Committee reform recommendations.

${ }^{\text {ii Rep. Loretta Sanchez (D-CA). Hearings before the House Select Committee on Homeland }}$ Security, Subcommittee on Rules, May 19, 2003.

iii These important laws include the creation and reauthorization of the Food For Peace Program (in 1954 and 1966); all major highways bills (1956, 1965, 1966, 1970, 1973, 1991, and 1998), all major urban mass transit bills (1964, 1970, 1974, 1982, and 1987), all campaign finance reforms acts (1972, 1974, and 2002), the Martin Luther King holiday (1983), and General Revenue Sharing (1972).

${ }^{\text {iv }}$ Because logarithms are undefined at zero, and many categories will have zero entries we added a very small fraction (.000001) to the actual proportions (estimates for $\mathrm{P}(\mathrm{x})$ ).

${ }^{v}$ The Bolling-Hansen reforms also permitted multiple referrals for the first time.

${ }^{\text {vi }}$ For example, the "Intergovernmental Relations" subtopic code contained every bill identified as falling within the General Revenue Sharing jurisdiction created in 1975. In addition, this subtopic included other bills that would create intergovernmental advisory commissions and intergovernmental grants, and therefore would be designated as related.

vii Three jurisdictions (Holidays, Rural Development and Tourism) were deemed to have no closely related subtopics and thus were not included in this analysis.

${ }^{\text {viii } B y}$ our measure of closely related bills, Ways and Means ranks highly on the expertise scale for several jurisdictions because tax and tariff related bills are coded into the substantive subtopics (rather than the taxation subtopic) whenever possible. Therefore, we exclude tax and tariff bills from our analysis.

${ }^{\text {ix }}$ We employ a poisson distribution because the dependent variable is a count of bills.

${ }^{\mathrm{x}}$ In one case, Mass Transit, the gaining committee was significantly less interested in the issue area. 
${ }^{\mathrm{xi}}$ Robust standard errors are used to address issues of normality or homogeneity of residual variance. We also include fixed effects indicators for both committees and jurisdictions.

${ }^{x i i}$ While the variance inflation factors (VIF) are in the moderate range, none goes above 7.

xiii Nevertheless, there are many published examples of situations where lawmakers pursue and Congress enacts changes that are not obviously reelection-oriented and possibly even "public spirited" (Fenno 1973; Parker 1996; Mayhew 2000; Becker 2005). 